\title{
The three logics of sustainability-oriented hybrid organisations: a multi-disciplinary review
}

\author{
Dina Hestad $^{1}$ (I) $\cdot$ J. David Tàbara² Thomas F. Thornton $^{1}$
}

Received: 3 October 2019 / Accepted: 15 November 2020 / Published online: 22 December 2020

(c) The Author(s) 2020

\begin{abstract}
Given current limitations of global and national governance arrangements in redirecting economic globalisation towards a climate-safe and sustainable world, it is crucial to understand how organisations that aim to tackle social and environmental problems using market mechanisms can contribute to fostering sustainability transformations. This review identified 60 different terms or concepts for hybrid organisations aiming to solve social and ecological problems through market related activities, reflecting a high degree of discontinuity and inconsistency in the literature. To assess the contribution to societal transformations of this array of innovative ventures, we introduce and operationalise Sustainability-Oriented Hybrid Organisations (SOHOs) as an umbrella concept to carry out a comprehensive review of 126 scientific articles that discuss them. Unlike traditional enterprises who apply one logic (commercial) and social and environmental enterprises who combine two logics (social-commercial or environmental-commercial), SOHOs unite commercial, social, and environmental logics, beliefs, and practices simultaneously - thereby adopting a higher level of organisational hybridity. SOHOs are oriented towards achieving net-positive sustainability and consider future generations and global socio-ecological systems which makes transforming enterprises towards SOHO models a potentially significant intervention point for promoting sustainability transformations. However, the narratives and actions of SOHOs can perpetuate rather than ameliorate the underlying causes and differential impacts of complex problems like climate change, unless the organisations adopt systemic, global, long-term, and socio-ecologically embedded strategies.
\end{abstract}

Keywords Global environmental change $\cdot$ Hybrid organisations $\cdot$ Sustainability $\cdot$ Transformations $\cdot$ Business models

Handled by Eefje Cuppen, Governance of Sustainability, Universiteit Leiden Instituut, Netherland.

Supplementary information The online version contains supplementary material available at https://doi.org/10.1007/s1162 5-020-00883-х.

\section{Dina Hestad}

dinahestad@outlook.com

1 Environmental Change Institute, University of Oxford, Oxford University Centre for the Environment, South Parks Road, Oxford OX1 3QY, UK

2 Institute of Environmental Sciences and Technology At the Autonomous University of Barcelona, Sustainabilogy, Cisa 11b, 08338 Premià de Dalt, Barcelona, Spain

\section{Introduction}

While economic globalisation has arguably taken millions of people out of extreme poverty, it is also true that unharnessed market forces, combined with other global trends, are compromising Earth's life-support systems which may seriously reduce humanity's options to achieve sustainable development (Asrar et al. 2019). As shown by the failure of the UN Climate Summit in Copenhagen in $2009,{ }^{1}$ followed by the weak commitments of the UN Climate Summit in Paris in $2015,{ }^{2}$ global and national governance arrangements seem insufficient in redirecting economic globalisation in a way that can secure a climate-safe and sustainable world. Given that economic market principles are nearly 'everywhere', and it is almost impossible to escape from the monetary economy and exchanges in our daily lives (Simmel

\footnotetext{
1 The fifteenth Conference of the Parties (COP) to the United Nations Framework Convention on Climate Change (UNFCCC).

2 UNFCCC COP 21.
} 
2004), it is crucial to improve our understanding of the role of new forms of economic agency-in particular organisational models and entrepreneurship processes aiming to tackle both social and environmental problems using market instruments. After all, long-lasting sustainability transformations are likely to emerge from endogenous learning of the agents involved in a given complex socio-ecological system (Tàbara and Pahl-Wostl 2007). Agents aiming to influence the course of development towards sustainability, sooner or later, will likely have to adopt or take advantage of the dominant tools, mechanisms, and incentive structures present at any given time and place, which in our globalised societies relate to global and local market economies.

One new and pivotal opportunity for that endeavour is hybrid organisations that combine multiple sustainability oriented institutional logics. Institutional logics are broad belief systems which influence cognition and guide decision making in an institutional field (Friedland et al. 1991; Greenwood et al. 2002; Ocasio 1997). They are the shared underlying social prescriptions that influence what are legitimate organisational goals and how to reach them (Scott and Meyer 1994). Traditional enterprises operate with one logic-namely a commercial one, whereas social and environmental enterprises combine either a social or environmental logic with that of a commercial logic - thereby spanning traditional public, private, and non-profit sectors (Haigh and Hoffman 2014; Schaefer et al. 2015; Smallbone et al. 2001). As such, these organisations tend to focus on addressing either social or ecological problems, not both. Although addressing environmental problems is inherently good for society as a whole (Millenium Ecosystem Assessment 2005), environmental initiatives can create unintended and adverse negative effects on individuals and communities such as excluding them from ecological benefits (Martí 2018). Or vice versa, focussing only on social problems can result in environmental damage (Hockerts et al. 2018).

Focussing solely on reaching a social or environmental goal through commercial means can blind individuals in organisations to their actions causing new or perpetuating existing problems at other levels, times, locations, or scales. For instance, environmental enterprises engaged in plantation forestry for carbon offsetting are found to have adverse negative effects on the livelihoods of local communities-especially through the destruction of crops and the limiting of access to, and use of, areas in and around the plantations (Lyons and Westoby 2014). Socially focussed enterprises that engage in microfinance also have environmental ramifications-especially through funding projects that are harmful to the environment or that could increase the environmental risks of clients (Huybrechs et al. 2019). Furthermore, increasingly questions are being posed regarding the scientific evidence for positive social impacts of microfinance lending (Roodman 2012).
Instead, to promote equitable sustainability transformations and to tackle the multifaceted problems that currently face society, such as climate change and social inequalities, hybrid organisations should as much as possible consider and address social and ecological problems simultaneously (Hockerts et al. 2018), and ideally implement regenerative practices that have net-positive outcomes (Robinson and Cole 2015). This is not to say that organisations with single or dual-logics cannot contribute to certain sustainability outcomes, but that individuals within hybrid organisations such as social and environmental enterprises, and their umbrella organisations, need to be cognisant of not creating new or perpetuating existing problems as a result of their actions.

A growing number of entrepreneurs are acknowledging and acting on the need to address social and ecological issues in an integrated way. A myriad of concepts and terms have been used to describe these ventures in different academic fields, including environmentally focussed social enterprises, ecological sustainability entrepreneurship, sustainability enterprises, sustainability entrepreneurship, sustainability venturing, benefit corporations, and triple bottom line businesses. This growing plurality of terms has resulted in diverging analyses and conflicting findings (Boyd et al. 2017; Gast et al. 2017) making it hard to determine the distinguishing features of these organisations and their direct outcomes and broader impacts on the promotion of transformations towards sustainability. In light of this, calls have been made to increase convergence within sub-fields of entrepreneurship research (Muñoz and Cohen 2018b; Schaltegger and Wagner 2011), and for research on sustainability venturing to take the step into sustainability science to better understand the socio-ecological interactions that such organisations engage in and their impacts (Muñoz and Cohen 2017). Examples of such organisations include the renewable energy cooperative Som Energia which aims to democratize and green the Spanish energy system and Proximity whose mission is to transform Myanmar's agricultural system into a vibrant source of food production, jobs and incomes for rural households while preparing Myanmar for the dual challenges of climate change and population growth.

In this article, we introduce the concept of SustainabilityOriented Hybrid Organisations (SOHOs) to understand if and how these organisations can be seen as distinct from social and environmental enterprises, and to understand their potential to promote equitable sustainability transformations. The $\mathrm{SOHO}$ concept acts as an umbrella category for organisations that unite commercial, social, and environmental logics, beliefs, and practices through aiming to tackle social and environmental issues while generating a sufficient amount of their income from trading in goods or services, so as to make them economically viable and self-sustaining. We now turn to consider the relevant theoretical background on 
sustainability transformations, hybrid organisations, particularly those of social and environmental enterprises-before exploring the distinguishing features of SOHOs and their transformative capacity.

\section{Theoretical background}

\section{Sustainability transformations}

Sustainability transformations, which are fundamental changes in the attributes of natural and human systems (Field et al. 2014a, b), are increasingly called for both in academia and practice to tackle current unsustainable and inequitable trends in the use of the earth's resources, due to the thus far highly limited success of incremental approaches (Field et al. 2014a, b; Matyas and Pelling 2015; O'Brien 2012). Sustainability science and sustainability transformations research has not adequately focussed on the role of organisations, and organisational transformations in fostering transformations towards sustainability. This despite the fact that the needs of societies are met through organisations, and decisions and actions made within them have impacts on global system dynamics. Sustainability science researchers have argued for the need for 'corporate biosphere stewardship' which focusses on looking after and caring for socio-ecological systems (Folke et al. 2019), for understanding the social values that drives a corporation to engage in corporate social responsibility (Fordham and Robinson 2019), and that investors should respect planetary boundaries and invest in solutions to environmental problems (Butz et al. 2018). These approaches rarely question the nature by which collective action is organised and its consequences on socio-ecological relations, but instead focus on incremental change and efficiency gains within existing systems and organisational forms. More fundamental changes are needed as "becoming a sustainable business often entails an organizational transition rather than an optimization of the existing" (Loorbach and Wijsman 2013, p. 26).

O'Brien and Sygna (2013) argue that transformations occur across three interacting and embedded spheres, namely the practical, political, and personal. It is vital to consider these in conjunction, as the personal sphere which "includes individual and collective beliefs, values and worldviews that shape the ways that the systems and structures (i.e., the political sphere) are viewed, and influence what types of solutions (e.g., the practical sphere) are considered "possible"" (O'Brien and Sygna 2013, p. 5). Transforming organisational models and by extension the economic systems in which they are a part, away from only pursuing economic growth, towards ones that combine social, environmental, and commercial concerns equally and simultaneously has the potential to act across these three spheres and result in non-linear transformations towards a world that is characterised by equitable and regenerative sustainability.

\section{Hybrid organisations}

According to new institutionalism, an organisational form is an "archetypal configuration of structures and practices" which is "regarded as appropriate within an institutional context" (Greenwood and Suddaby 2006, p. 30). Key organisational categories include public, private, and non-profit organisations and their distinctions are based on the assumption that organisations within these descriptors inhabit generic features that are 'pure' and indicate membership of these 'distinct' sectors (Billis 2010). These sectors have specific logics-which includes beliefs, practices and rationales, and aligning with these helps organisations gain legitimacy (Romanelli 1991). Billis (2010, p. 6) has outlined that the private sector is: "(a) owned by shareholders and (b) governed according to the principle of size of share ownership, working according to (c) operational priorities driven by principles of market forces in individual choice, with typical (d) human resources consisting of paid employees in a managerially controlled firm and (e) other resources primarily from sales and fees". While the public sector is "(a) owned by the citizens and (b) governed according to principles of public elections with work driven (c) by principles of public services and collective choice and as its typical (d) human resources consisting of paid public servants in legally backed bureaux and (f) resourced by taxation" (Billis 2010, p. 6). Lastly, the non-profit sector (also often called the third sector) has as a goal to improve social and environmental problems, is membership owned, governed by elected representatives, their staff is a combination of volunteers and employees, and they generate revenue through donations, legacies, and membership fees (Doherty et al. 2014).

However, boundaries between public, private, and nonprofit organisations are becoming increasingly fluid and blurred (Billis 2010; Doherty et al. 2014; Battilana and Dorado, 2010). Organisations that span institutional boundaries and operate with more than one institutional logic and organisational domain have been called hybrids (Battilana and Dorado 2010; Battilana and Lee 2014; Pache and Santos 2011), defined as "structures and practices that allow for the coexistence of values and artefacts from two or more categories" (Doherty et al. 2014, p. 418). There are various forms of hybrid organisations applying various combinations of the public, private, and non-profit sectors. For instance, government owned enterprises breach the private and public sphere, for-profit cooperatives breach the private and nonprofit sphere, and social enterprises combine public, private, 
and non-profit beliefs, practices and rationales by aiming to improve public goods such as social and/or environmental commons through market related mechanisms.

In doing so, it has been argued that hybrids are creating new institutions, in the form of new rules for governing social interactions, which pose a challenge to mainstream forms of economic organising (Wilson and Post 2013). This especially stems from the fact that the emergence of these hybrid organisational forms, such as social enterprises, come from an ideological standpoint that considers that the state is not or should not be the only or even the main agent responsible for environmental governance-due to its failure to address key sustainability issues such as halting the rapid loss of biodiversity and stopping negative trends in GHG emissions (Battilana and Lee 2014). As such, these types of hybrid organisations are taking responsibility for various sustainability related problems that the public sector has failed to adequately address. Other reasons for the emergence of these hybrid organisations relate to a lowering of trust in corporations after the global financial crisis amongst the general public (Hiller 2013), as well as a desire from NGOs to be less dependent on donations and subsidies (Battilana and Lee 2014).

The number and diversity of hybrid organisations has grown significantly in the last two decades, particularly ones with both social and/or environmental missions and economic practices (Hoffman et al. 2012) and several legal forms have come about in different countries to accommodate them. These include, among others, the LC3 Statute (Low Profit Limited Liability Company), Benefit Corporation (B-Corp) and Flexible Purpose Corporations in the US, the CIC Regulations (Community Interest Corporations) in the UK, and the Social Purpose Company in Belgium (Stubbs 2017). Such statuses can legally protect officers and directors and allow them to balance shareholder returns with social and environmental impacts (Stecker 2016).

Social, environmental, and sustainability-oriented enterprises are key examples of hybrid organisations. Thompson et al. (2011) argues that these entrepreneurial forms have many similarities but should be considered distinct from each other as well as from commercial enterprises-which will be further elaborated on later in the article. Thompson et al. (2011) also argue that these hybrid organisations raise unique questions and phenomena but should not be considered their own fields of study, instead they represent an interesting context for studying key questions in the field of entrepreneurship, and we would add that is also the case for sustainability science. Key among these are questions surrounding the potential and actual outcomes and impacts these organisations have on sustainability.

\section{Social enterprises}

Social enterprise is a concept that has received a great deal of attention in the organisational literature, with a "bewildering array" of definitions (Teasdale 2012, p. 1) and large amounts of empirical and theoretical papers (Battilana and Lee 2014; Bull 2008; Doherty et al. 2014; Jones and Donmoyer 2015; Smith et al. 2013) but no consensus on their distinguishing characteristics or impacts (Chliova et al. 2020). Although some argue that social entrepreneurship is not distinct enough to warrant its own body of theory (Dacin et al. 2011) others emphasise their theoretical uniqueness or their distinguishing features.

Those who argue that social enterprises are distinct from governments, charities, commercial entrepreneurship, and social activism underscore that social enterprises are driven by a motivation to create value for society, not to capture value (Santos 2012), or in other words their concern for social issues goes beyond economic return (Thompson et al. 2011). However, what social value entails is wide and expanding. Battiliana et al. (2012, p. 3) states that social entrepreneurs seek to "address social issues in domains as diverse as hunger, health care, economic development, environment, education, housing, culture, law, and politics". With examples being organisations like the microfinance organisation Grameen Bank, Benetech which creates software for social good that serves humanity and empowers people to improve their lives, and Building Markets which has the goal to drive job creation and inclusive economic growth in crisis-affected countries by connecting local SMEs to supply chains and investment. This wide scope has been criticised by Thompson et al. (2011), especially for including environmental considerations within the social category, as this creates confusion. Instead, they urge scholars to narrow the term "social" to distinguish it from other entrepreneurship forms and that environmental and sustainable entrepreneurship should be considered as distinct (Thompson et al. 2011).

\section{Environmental enterprises}

Environmental enterprises and entrepreneurship concerns combining the creation of environmental value in the form of preservation and in some cases regeneration of the natural environment with the pursuit of economic value (Isaak 2016; Lenox and York 2011; Schaefer et al. 2015). Researchers of these organisations have coined terms like eco-entrepreneurship, ecopreneurship, green enterprise and entrepreneurship, and environmental enterprise and entrepreneurship (Allen and Malin 2008; Ebrahimi and Mirbargkar 2017; Gibbs 2006; Harini and Meenakshi 2012; Hendrickson and Tuttle 1997; Hörisch et al. 2017; Lenox and York 2011; Mars and Lounsbury 2009; Pastakia 2002; Sarah and Candifford 
2007; Schaper 2002). These organisations typically take on a for-profit form (Kirkwood and Walton 2010), and has an environmental mission that is either of lesser or equal importance to commercial goals (Pastakia 1998; Thompson et al. 2011). Thompson et al. (2011, p. 220), argue that environmental entrepreneurship and enterprises can be considered unique due to their exclusive focus on environmentally relevant market failures, their "environmentally relevant motivations and socio-cultural norms and examining opportunities that produce both economic and ecological benefits." With some environmental entrepreneurs not only motivated by economic gain, but also by ethical commitments to future generations (Anderson and Leal 2001). Examples of these types of organisations are renewable energy corporations such as Statkraft, carbon offset companies like Green Resources, and companies that sell eco-friendly products such as Seventh Generation Inc. Dean and McMullen (2007, p. 58) defines environmental entrepreneurship as a "process of defining, evaluating, and exploiting economic opportunities that are present in environmentally relevant market failures", and further outline that it should be considered a subset of sustainable entrepreneurship. Placing environmental entrepreneurship as a sub-set of sustainable entrepreneurship has, however, been criticised as it promotes ambiguity in a field that requires clarity. Environmental entrepreneurship can and should be distinguished due to its exclusive focus on creating economic and ecological benefits simultaneously (Thompson et al. 2011). As such, social and environmental enterprises integrate only two logics, social-commercial or environmental-commercial. But what about those that integrate all three logics? Finding out what distinguishes these organisations and understanding their potential for promoting sustainability transformations will be the focus of the remainder of this article.

\section{Methods}

Our review encompasses research on organisations that aims to solve social and environmental problems through market related mechanisms. We began the search widely by looking for all articles published related to SOHOs as previously defined in an operational guise. Specifically, extensive keyword searches were conducted in ABI Inform (Proquest) among the largest business-related academic databases (Schaefer et al. 2015), as well as the more general databases of Scopus and Web of Science. Titles, abstracts, and subject headings were searched using variations of the search terms: hybrid organisations and sustainability; social enterprise/ entrepreneurship and sustainability; ecoenterprise/entrepreneurship, environmental/green enterprise/entrepreneurship; sustainability entrepreneurship; community enterpr*, civic enterpr* and sustainability; benefit corporations and sustainability. This search revealed over 700 peer-reviewed academic articles, with the majority of the articles focussing on addressing either social or ecological problems. The titles and abstracts of these articles were manually reviewed to determine which papers considered organisations involved in solving both social and environmental problems using market-based mechanisms. Articles that did not include, or only peripherally looked at such organisations were removed. Additionally, we only reviewed peer-reviewed journal articles hence books, book chapters, and book reviews were not included. This resulted in 77 articles. We also conducted a reverse search approach, where additional papers were identified from the citations of the selected journal articles. This generated a further 49 articles. In total, 126 articles were included in the final review sample.

We coded the articles for: descriptive information about the article (e.g., journal, discipline, geographical focus); term used for the organisation; methodological details; focus of study; theoretical approach; first order codes; and emerging themes. This wider review helped highlight how SOHOs differ from traditional, social, and environmental enterprises. To answer the research question on assessing the contribution of SOHOs to societal transformations we identified 40 articles that considered the direct outcomes and broader impacts of SOHOs. We coded these articles according to first order codes and second order themes. Later in the review process we also considered some of the questions developed by Tranfield et al. (2003) for assessing qualitative research regarding sampling strategy, data quality, and generalizability to improve the reliability of the analysis. We have included a sample of the data extraction form used to analyse these articles in the supplementary material.

\section{Results}

\section{Publication trends}

Since 1998 there has been a positive trend in the amount of papers published related to organisations with both social and ecological purposes and practices, with a peak in 2018, where 21 articles were published (see Fig. 1).

The majority of papers $(n=126)$ were published in the field of business and management studies (86) with the Journal of Business Venturing having the most papers published (12) followed by the now discontinued Greener Management International (8), the Journal of Business Ethics (7) and Journal of Cleaner Production (6). Sustainability Science was the second largest academic discipline (10) followed by geography and organisational studies ( 8 papers each). The rest were published within a range of social science disciplines such as development studies, sociology, and political science. The articles in the review use a variety 
Fig. 1 Trend in publications

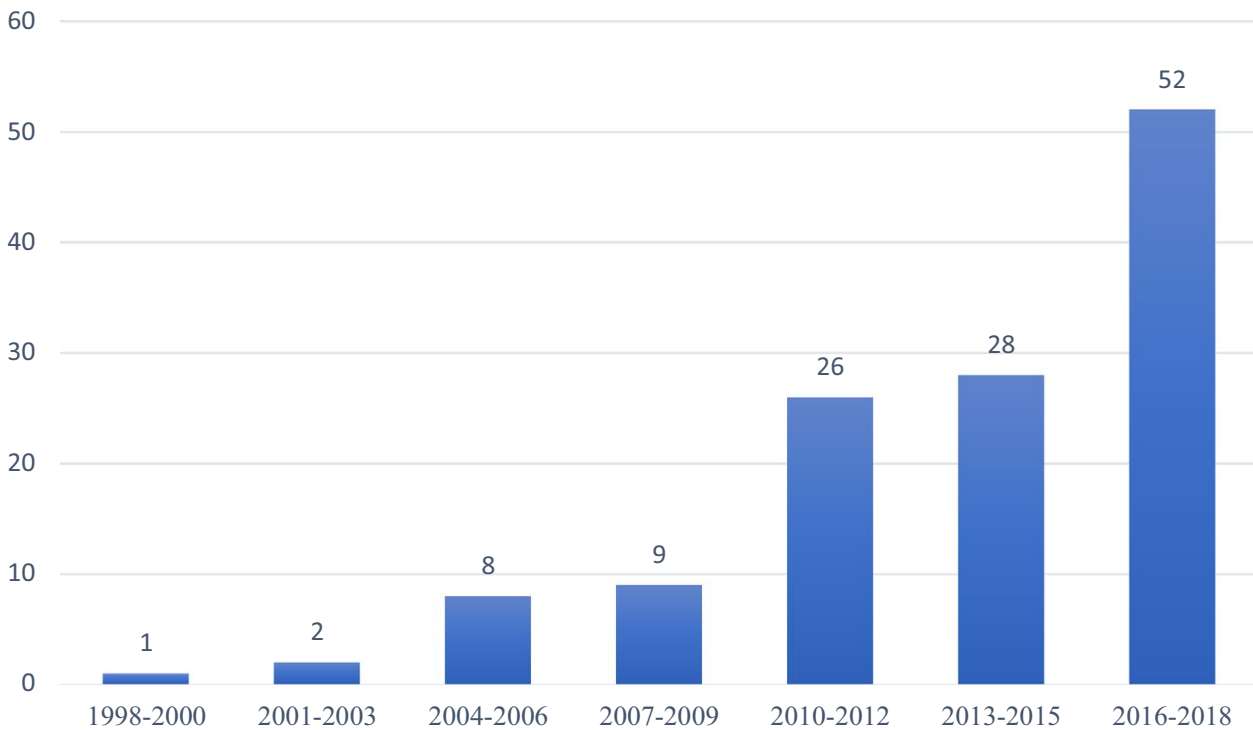

of methodological approaches. The majority of the papers applied qualitative methods (77), whereas only eight used quantitative approaches and five applied mixed methods. Additionally, 36 papers were conceptual. Over half of the literature has focussed on or have main authors based in the Global North (82), with the Global South getting significantly less attention (28). The rest of the articles were multi-national or international studies often with case studies both in the Global North and the Global South (16). The US (29) and the UK (14) were the countries with the most publications.

We identified 60 different terms and concepts for organisations with social and ecological purposes and practices within the reviewed articles. The majority of these were variations of terms such as environmental/eco enterprise/ entrepreneur/entrepreneurship, green enterprise/entrepreneur/entrepreneurship, social enterprise/entrepreneur/ entrepreneurship or sustainability enterprise/entrepreneur/ entrepreneurship but also terms like benefit corporations, community enterprises, prosocial organising, renewable energy cooperatives, and triple bottom line businesses. The articles were deliberately chosen for this review based on the fact that they considered organisations that aimed to reach their social and environmental missions through marketbased mechanisms, thus making them sustainability-oriented hybrids spanning the private, public and non-profit realm.

\section{Sustainability-Oriented Hybrid Organisations as an umbrella concept}

A growing number of the entrepreneurs behind hybrid organisations are acknowledging and acting on the need to address both social and ecological issues simultaneously (Schaltegger and Wagner 2011). And an associated literature has emerged that study these organisations, particularly sustainable venturing (Muñoz and Cohen 2017, 2018a) and sustainable or sustainability entrepreneurship (Hörisch 2015; Parrish 2010; Parrish and Foxon 2006; Schaltegger and Wagner 2011). In fact, this review has identified 60 different terms and concepts used to describe organisations engaging in both social and ecological practices stemming from multiple academic fields. Figure 2 showcases that the 60 terms and concepts used in the 126 reviewed articles fit under the SOHO umbrella concept. This showcases the divergences and contradictions that exist within research on these organisational processes and makes it challenging to understand if and how the organisations considered in these articles are distinguishable from other forms of entrepreneurship and what outcomes and impacts might arise from their actions. Due to space constraints and as each of the terms can be defined as a SOHO all 60 terms are not specifically mentioned in the following literature review.

In other fields, umbrella categories have proven helpful in integrating sub-domains, identifying differences, and assessing current knowledge, such as sustainable cities (de Jong et al. 2015). The Sustainability-Oriented Hybrid Organisations (SOHOs) umbrella category describes the vehicles that sustainability entrepreneurs create to contribute to environmental quality and social well-being through market related measures. Although one term for such organisations would be preferable in the long term, as a first step this umbrella category enables consolidation of knowledge about these organisations regardless of which term or organisational form is applied. For instance, organisations such as social enterprises, alternative organisations, cooperatives, community and civic enterprises, environmental enterprises, employee-owned businesses, social firms, next-stage organisations, and sustainability enterprises, are SOHOs as long as 
Fig. 2 Terms used for organisations that fit under the SOHO umbrella in the reviewed articles

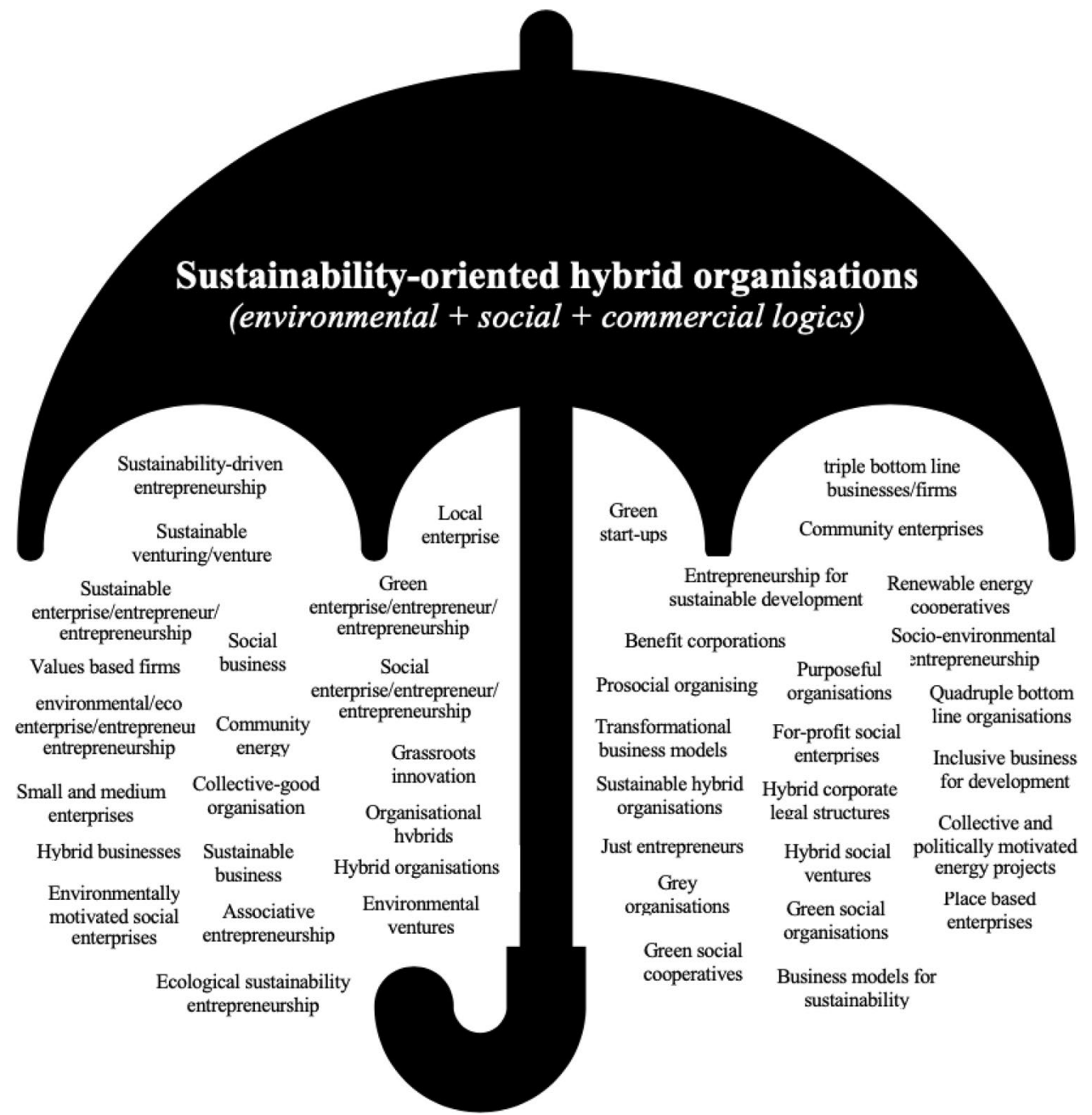

they integrate social, environmental, and commercial missions and practices.

\section{Distinguishing features of SOHOs}

The above discussion of social and environmental enterprises has highlighted that the main distinguishing factor between SOHOs and their entrepreneurs and social and environmental enterprises is the combination of three logics: social, environmental, and commercial. This is because these organisations aim to create environmental, social and economic value simultaneously. Yet, social and environmental enterprises and entrepreneurship should not be considered a sub-set of SOHOs or sustainable entrepreneurship according to Thompson et al (2011), as not all social or environmental missions are sustainably oriented or have sustainability outcomes. For instance, "ventures that focus on resolving a social issue, such as improving education for inner-city youth in the US, may very well be (1) willing to struggle economically as long as their intent to resolve a social mission stays intact, (2) driven by altruistic motivations, and (3) focused on the social benefits over other competing considerations, they would not necessarily fall into the context of sustainable entrepreneurship" (Thompson et al. 2011, p. 215). Additionally, situating sustainable entrepreneurship and SOHOs as a sub-set of social entrepreneurship, as suggested by Dean and McMullen (2007), promotes ambiguity. Although sustainable entrepreneurs aim to solve social issues, this is not their only focus, and researchers emphasising this one aspect of their mission can miss out on understanding the full social-environmental context of their transformational capacity toward regenerative sustainability.

Table 1 highlights in greater detail the similarities and differences between SOHOs and social and environmental enterprises. The key distinguishing factors relate to the primary logic, the tensions within the organisations, their degree of consideration of time and scale and intended impact of their actions. The first three will be considered in this section, whereas the latter will be considered in Sect. 6.4.

As already highlighted the logic and products of social enterprises are social change and well-being amongst 
Table 1 Key features of social enterprises, environmental enterprises, and SOHOs

\begin{tabular}{|c|c|c|c|}
\hline & Social enterprises & Environmental enterprises & SOHOs \\
\hline Definition & $\begin{array}{l}\text { An organisation that applies busi- } \\
\text { ness principles to solving social } \\
\text { problems }\end{array}$ & $\begin{array}{l}\text { An organisation that applies } \\
\text { business principles to solving } \\
\text { environmental problems }\end{array}$ & $\begin{array}{l}\text { An organisation that applies busi- } \\
\text { ness principles to solving social } \\
\text { and environmental problems }\end{array}$ \\
\hline Wealth distribution & Shareholder and/or stakeholder & Shareholder and/or stakeholder & Shareholder and/or stakeholder \\
\hline Predominant organisational form & Non-profit or profit & Profit & Non-profit or profit \\
\hline Primary logic & Social change/well-being & $\begin{array}{l}\text { Environmental change/minimising } \\
\text { harm }\end{array}$ & Holistic/net positive sustainability \\
\hline Tensions & $\begin{array}{l}\text { Economic sustainability versus } \\
\text { social mission }\end{array}$ & $\begin{array}{l}\text { Economic sustainability versus } \\
\text { environmental mission }\end{array}$ & $\begin{array}{l}\text { Between all three logics (social, } \\
\text { environmental, commercial) }\end{array}$ \\
\hline Scale and time considered & $\begin{array}{l}\text { Present generation and immediate } \\
\text { social system }\end{array}$ & $\begin{array}{l}\text { Present generation and immediate } \\
\text { environmental system }\end{array}$ & $\begin{array}{l}\text { Future generations and global socio- } \\
\text { ecological system }\end{array}$ \\
\hline Intended impact & Social change & Environmental change & Transformative/systems change \\
\hline \multirow[t]{3}{*}{ Examples } & Benetech & Statkraft & Planting Empowerment \\
\hline & Building Markets & Green Resources & Som Energia \\
\hline & Grameen Bank & Seventh Generation Inc & Proximity \\
\hline
\end{tabular}

their target audience. For environmental enterprises this is positive environmental change-most often in the form of minimising harm to the environment. SOHO entrepreneurs on the other hand aim to promote net positive sustainability, often regenerative sustainability, and their "product" or ideal impact is to transform systems away from unsustainable practices (Hestad et al. 2020). The entrepreneurs behind SOHOs design their businesses, economic models, and strategies in a way that allows them to address a particular sustainability challenge rather than "greening" existing practices (Nielsen and Samia 2008), which is often the case with environmental enterprises. In so doing they "seek to create social and environmental improvements through their practices and products" (Haigh and Hoffman 2012).

SOHOs are oriented towards both present and future generations. With respect to the present they tend to have close and committed relationships with various stakeholders, distributors, and local communities (Haigh and Hoffman 2014). This often means that SOHOs "create close relationships with communities by employing local people, involving them in decision-making, training them in specific sustainable techniques (such as low impact agriculture and reforestation), and paying above-market wages that enable a better quality of life" (Haigh and Hoffman 2012, p. 10). For instance, this has been found to result in the building of social capital and stronger connections and a "spirit of trust and collaboration" (Diaz-Correa and Lopez-Navarro 2018, p. 13), and the strengthening of local communities and increased natural resource awareness (Allen and Malin 2008). Additionally, there is evidence that SOHOs help build community resilience and social capital after disasters (Berno 2017). Additionally, SOHOs deliver sustainability outcomes that ensures rather than compromises the needs of future generations (Hestad 2019), especially through the orientation towards transforming systems away from unsustainable processes and practices.

SOHOs often intentionally synchronise their venture activities with the natural cycles of the social and ecological contexts in which they operate (Muñoz and Cohen 2017). The more embedded they are in the socio-ecological systems, the more likely they are to be synchronised or in tune with socioeconomic and biophysical cycles both locally and globally. A key example is Planting Empowerment a Panamanian-American forestry company who "works with Panamanian farmers living on deforested land to re-forest and generate sustainable household income" (Muñoz and Cohen 2017, p. 2). Entrepreneurs within SOHOs have been found to have a more integrated socio-ecological worldview, where the organisation is seen as an integral part of global socio-ecological systems (Hestad et al. 2020). Such an orientation influences how the organisation conceptualises and integrates social and environmental logics. The more integrated the understanding of socio-ecological interactions are among key members of the organisation the less likely it is that one logic - typically that of sustaining economic growth-takes precedence over the others (Hestad et al. 2020).

However, tensions are common-especially if the organisation is big and includes staff that have experience from different organisational logics and archetypes (traditional or other hybrids) (Battilana and Dorado 2010). Tensions that SOHOs face are both similar and unique to hybrid organisations that combine two logics. They are similar in that they apply multiple logics to gain support from different stakeholders and generate an organisational identity which balances between such logics (Battilana and Dorado 2010). But instead of having to manage two logics, they need to manage three. This can mean that they can "face 
unintended consequences of that institutional complexity... which may impede their efforts" to address social or environmental problems (Jay 2013). It can become a "balancing act between short-term economic objectives and long-term sustainability objectives" (Jolink and Niesten 2015, p. 293). Hybrids such as SOHOs might have to maintain the tensions rather than resolve it (Ashforth and Reingen 2014), and one way of doing so is through learning how to "engineer a compromise among internal members and to enforce change among external institutions to maintain its sustainability" (Turcato et al. 2012, p. 38).

\section{Direct outcomes and broader impacts of SOHOs}

We have established why SOHOs are distinct from social and environmental enterprises, and now we turn to considering the direct outcomes and broader impacts of SOHOs to understand their potential for promoting sustainability transformations. We define outcomes in terms of finite and measurable medium-term changes that come about as a direct result of socio-ecologically oriented actions. Impacts, by contrast, are classified as broader effects, particularly the longer-term consequences of an outcome. Outcomes and impacts relate to the effects SOHOs have on local as well as global socio-ecological processes and dynamics. Given the measurable and finite nature of outcomes we consider these at the micro, meso, and macro scales.

\section{Outcomes}

At the micro-scale, SOHOs and their practices have been found to generate both positive and negative outcomes for individuals and neighbourhoods in different contexts. This was highlighted by Holt and Littlewood (2015) who carried out a comprehensive study on the outcomes and impacts of SOHOs in sub-Saharan Africa. Across 20 cases, they found all resulted in significant economic benefits for their respective stakeholder groups, including going beyond those who worked for the organisation and towards their families and communities. However, they can also result in negative outcomes as found in the case of Cookswell (a SOHO in Kenya who produces, markets, and sells innovative energy saving charcoal and wood-fuelled stoves and ovens), such as insecure employment for workers, increased savings resulting in increased overall consumption, still some particle pollution and tree cutting, and no medical benefits provided to workers (Holt and Littlewood 2015).

Furthermore, an outcome that has been found to emerge on the micro scale relates to learning in individuals that can come about as a result of the way SOHOs organise themselves. In a case study on Som Energia, a Spanish renewable energy cooperative, Pellicer-Sifres et al. (2018, p. 110) found that not only did first order learning emerge but so did second order learning, where members started "questioning established values and reconsidering issues such as sustainability, power, justice and personal social relations". This is important as sustainability cannot be imposed, only learned (Tàbara and Pahl-Wostl 2007), and therefore, such cumulative learning outcomes could result in broader positive impacts.

On the meso-scale SOHOs have also been found to have beneficial outcomes on organisations, communities, cities, and regions, including on local and regional markets as well as biophysical dynamics. This stems from the fact that SOHOs do not only consider their impacts on the contexts in which they operate but that they "proactively work to shape this" through "forming new markets, influencing peers, and changing societal perceptions" (Glavas and Mish 2015, pp. 630-631). Furthermore, SOHOs "seek to diffuse acceptance of their business model throughout the institutions and markets in which they operate" (Haigh and Hoffman 2014). They encourage emulation by other companies and see it as a sign of success and do not create barriers for other companies to follow in their footsteps as is common in the mainstream market. Therefore, when they enter new sectors and markets they often have significant outcomes on the markets themselves as well as the incumbents within them as found by (Olofsson et al. 2018) in the Scandinavian electricity market.

The review found little research on outcomes that SOHOs have on the macro scale, namely the national and international level. This includes a focus on global markets, systems of governance and wider socio-ecological dynamics. This highlights a clear gap in knowledge about the outcomes of SOHOs.

\section{Impacts}

The literature has identified a number of broader and longerterm impacts, both actual and potential, that come about as a result of the actions and practices of SOHOs. One of the biggest potential impacts of SOHOs relate to changing institutions and the wider rules of the game (Haigh and Hoffman 2014). Specifically, this relates to SOHO's contributions to changing the way people view and conceive of the role of corporations in society, away from profit- only missions and towards enterprises focussing on making their socio-ecological missions profitable (Alberti and Varon Garrido 2017). Gismondi and Cannon (2012, p. 70) argue that SOHOs are "shifting the definitions of sustainability in a paradigmatic way, introducing a combined ethos alongside a blended return on investment, placing the focus on deeper social transformation, which generates new questions at the grassroots and civic levels and suggests alternate policy directions for governments and institutions". 
Furthermore, the literature shows that SOHOs that have close interactions and focus on mutual benefit can result in more sustainable and stable long-term supply of natural resources (Haigh and Hoffman 2014). When SOHOs partner with communities and governments they have the potential to help achieve a balance between humans and nature (Raufflet et al. 2008). This is linked to the fact that the entrepreneurs in visionary small-enterprises have been found to "readily make connections between nature and their businesses and were aware of value judgments they made either in favor of nature, or with some regret against it, where supporting infrastructure was absent, or economic rationalities prevailed" (Kearins et al. 2010). This nature-centred outlook has been considered a key element for businesses that are aligned with a new ecological paradigm (Kearins et al. 2010).

However, even though SOHOs might aim to create positive environmental and social impacts through their business models they have been found to also generate negative unintended impacts. Yet, only a few articles have investigated the negative consequences of environmentally and socially oriented business models thus far (Duke 2016; Martí 2018; Nahi 2016; Sanchez and Ricart 2010). Two categories of business models that can promote negative effects are "those for oppression or depletion and exclusionary ones" (Martí 2018, p. 965). This is the case, because they "reinforce power structures that marginalize the poor [oppression], deplete resources, or exploit particular communities; or conversely address specific societal problems, but unintentionally exclude some of the stakeholders they intend to positively impact" (Martí 2018, p. 973). One example of an exclusionary business model is the waste collection and recycling scheme which is outlined as having beneficial outcomes on the micro scale earlier in the paper. These have been found to act as exclusionary as those residents that cannot pay for collection services are not included in decisionmaking processes and the focus shifts towards areas, where people can pay for the service (Frediani et al. 2014).

In contrast to outcomes, the positive and negative impacts of SOHOs have been traced all the way up to the macroscale which will be highlighted in the discussion.

\section{Discussion}

As shown above SOHOs differ from traditional, environmental, and social enterprises, because they simultaneously integrate three distinct institutional logics. Traditional enterprises, in their most archetypical form, are unsustainable due to their single logic of profit maximisation and shareholder supremacy. They focus on short time horizons and do not consider the relationships and impacts they have on socio-ecological systems (Hestad et al. 2020).
Social and environmental enterprises tend to adopt a netzero sustainability approach, where the focus is either on making sure the enterprise itself does less harm, or that they facilitate that less harm is done in a sector or field than previously, but without challenging current system dynamics. Microfinance organisations, lauded as an archetypical social enterprise and hybrid organisation (Battilana and Dorado 2010), is a key example, as it provides the promise that poverty can be reduced through current financial mechanisms, without threatening current power and wealth concentrations (Roodman 2012). Another example relates to eco-friendly products-which can still promote unnecessary consumption-but it is consumption that can be viewed as 'less bad'. As such social and environmental enterprises focus on present generation and the immediate socio-ecological system context. Robinson and Cole argues that this approach has promoted a "prolonged inevitable environmental decline by aiming to make things 'less bad' as opposed to finding ways to rehabilitate and improve unsustainable circumstances" (Robinson and Cole 2015 , p. 133). This constraining approach has failed in engaging a broader range of people in coming up with creative alternatives, e.g., including in perception and in the questioning of knowledge, that promote systemic change, and instead is likely to induce apathy or denial (Gifford and Comeau, 2011; Shellenberger and Nordhaus 2004).

The goal of SOHOs is not to become less unsustainable-e.g., by doing less harm-but to become more sustainable (Haigh and Hoffman 2014), and to promote net positive effects on society through the improvement and restoration of natural and social capitals. This has been called regenerative sustainability, and is a perspective which focuses on sustainability being net-positive and maximising benefits (Robinson and Cole 2015); "merely eliminating further negative impacts is not enough" (Maggs and Robinson 2016, p. 186). SOHOs represents a narrative that shifts away from reducing negative human impacts towards a story, where people and organisations are cultivating positive human and biophysical impacts; people are not the problem, but the solution (Maggs and Robinson 2016). Additionally, SOHOs consider future generations and global socio-ecological systems in their work.

The framework in Fig. 3 showcases how SOHOs differ from traditional, social and, environmental enterprises. It shows how the integration of three logics along with consideration of future generations and global socio-ecological systems and their orientation towards net-positive sustainability makes them likely to have a greater capacity to contribute to transformations towards regenerative sustainability than traditional, social, and environmental enterprises. The traditional enterprise circle is closed as such organisations tend to be considered as environments in themselves with 


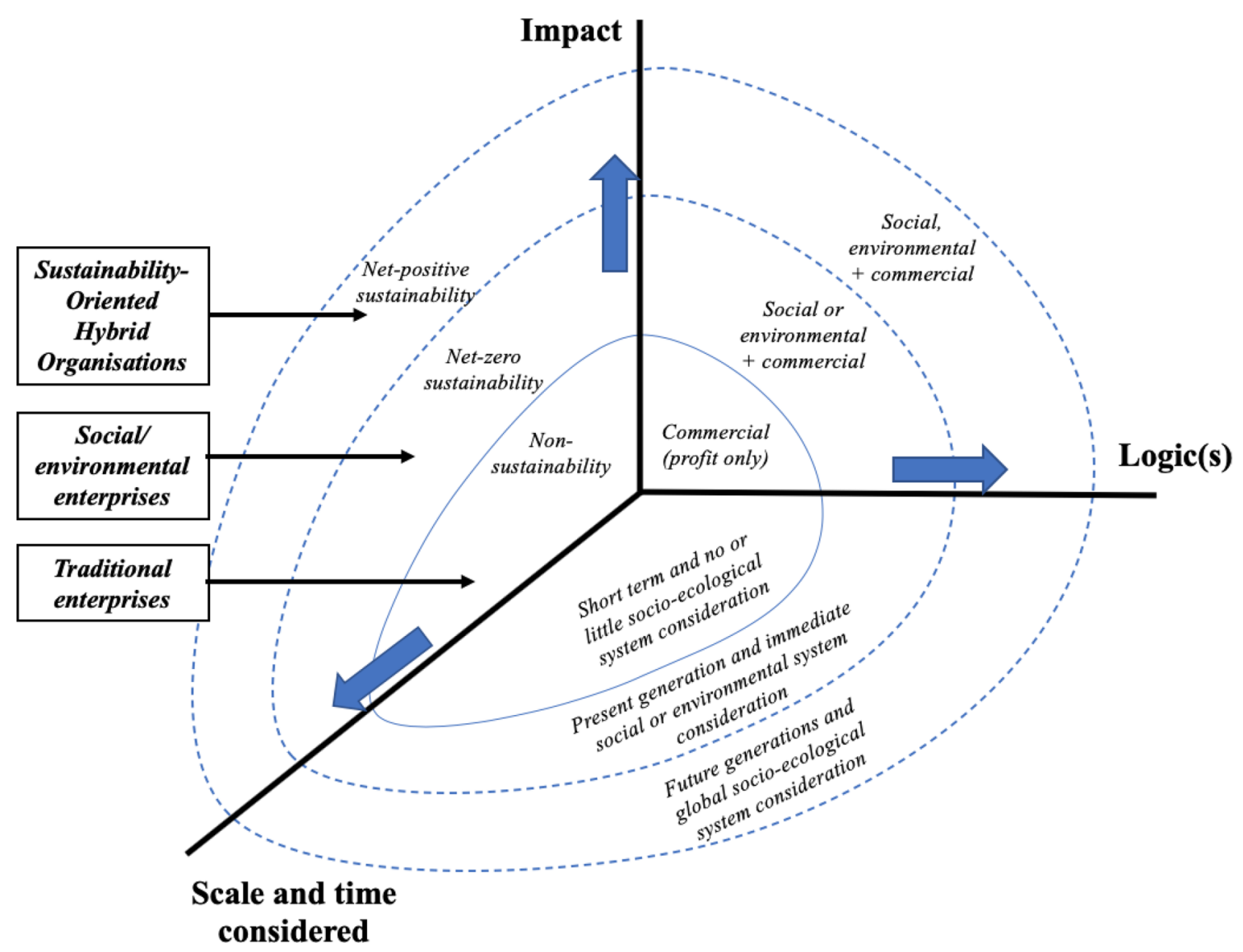

Fig. 3 Framework for understanding the sustainability impact of applying one, two, or three institutional logics

no or limited socio-ecological interactions, whereas the social/environmental enterprise and SOHO circles are open to reflect the interdependent relationship between organisation and socio-ecological systems (Hestad et al. 2020). Yet, SOHOs are not uniform, and the capacity of SOHOs to contribute to net-positive sustainability varies, hence more research is required to understand these variations and their impacts on the transformative potential of SOHOs-as will be outlined below.

Overall, we argue that changing mainstream organisations towards organisational forms such as SOHOs have the potential to contribute to the building of the conditions for the emergence of positive tipping points' (Tàbara et al. 2018) in the economy insofar they can tip the economic system toward a sustainability development trajectory. Such possible tipping interventions (Farmer et al. 2019; Otto et al. 2020) - which may emerge in organic ways that is not centrally controlled-cut across the three spheres of transformations outlined by O'Brien and Sygna (2013). Interactions across the three spheres are considered to have the largest potential for non-linear transformations ( $\mathrm{O}$ 'Brien and Sygna 2013). Organisational change is especially important, because organisations are where behaviours and technical solutions are realised, where social systems and institutions are re-produced or evolve, and where individuals enact discourses and paradigms. Emerging organisational forms such as SOHOs could contribute to "explicitly transforming self and society by providing products and services in a way that is healing ecological, psychological, and social ills" (Reynolds 2017, p. 141). As such, SOHOs could transform the economy from the inside.

There is a great deal of optimism about the potential impacts and contributions SOHOs can make to sustainability transformations in the organisation and management literature, especially through linking entrepreneurship and sustainable development (Hall et al. 2010). For instance, it is claimed that SOHOs can "solve social, economic, and environmental problems using the entrepreneurial engine and the profit instrument" and ultimately make capitalism anti-fragile (Hysa et al. 2018). Thompson et al. (2011) found that research on SOHOs is mostly conceptual, and empirical evidence of their outcomes and impacts is often lacking. Our review suggests that to a large extent this continues to be the case. More empirical research and improved framework and methods are needed to better understand whether the outcomes of SOHOs activities and processes are resulting 
in net-positive impacts for social and ecological systems and ultimately contributing to transformative change. This is not an easy challenge given the non-linear, cumulative, and complex dynamics associated with sustainability transformations. However, interesting research avenues in this domain could investigate whether SOHOs contribute to building transformative capacities in society, such as re-connecting social and natural systems, healthy human agency, and social cohesion (Ziervogel et al. 2016). This is important as these capacities have been identified as vital components in helping bring about sustainability transformations (Tàbara et al. 2018).

Additionally, questions have been asked regarding whether SOHOs are able to address the systemic and underlying causes of global environmental change (Westley and Antadze 2010). Identifying and addressing these underlying causes are deemed vital for achieving fundamental systems transformations. If these underlying causes are not addressed within their business models, SOHOs could perpetuate rather than ameliorate existing systemic problems and generate unintended negative effects. For instance, business models on waste collection and recycling have been found to promote a citizen as consumer model which does not encourage development of collective strategies to manage public spaces and instead perpetuates privatisation of basic services, where social needs are transformed into market opportunities (Frediani et al. 2014; Sharma and Mukherji 2015). In fact, these types of enterprises have been called 'neoliberalism by stealth' due to its contribution to the marketisation and privatisation of the welfare state (Nicholls and Teasdale 2017). As such, it is important to have a holistic view of what is considered net positive impacts and not only focus on proximate, and short-term positive outcomes as these could result in unintended negative impacts longer term and at higher scales. More research is needed on understanding root causes in different contexts and whether and how SOHOs are tackling the underlying root causes of issues like climate change and social inequality.

\section{Conclusion}

This paper has shown that the Sustainability-Oriented Hybrid Organisations umbrella term is a useful concept for classifying organisations that aim to address both environmental and social issues through commercial means. This term has enabled a comprehensive review of 126 scientific articles across disciplines to identify how SOHOs differ from traditional, social, and environmental enterprises and assess their contribution towards societal transformations. To assess their actual and potential contributions to bringing about societal transformations towards sustainability we considered 40 articles in depth on the direct outcomes and broader impacts of SOHOs.

We found that unlike traditional enterprises who apply one logic (commercial) and social and environmental enterprises who combine two logics (social-commercial or environmental-commercial), SOHOs unite commercial, social, and environmental logics, beliefs, and practices simultaneously-thereby adopting a higher level of organisational hybridity. Traditionally, environmental and social logics have been grouped together (most commonly under the social enterprise concept), which furthers the definitional ambiguity that is prevalent in the field. The SOHO concept helps resolve this ambiguity by making it clear that hybrid organisations can combine three distinct logics. This finding adds further complexity to the study of hybrid organising, and especially the concept of mission drift. A key question for further research is, therefore, how does hybrid organisations with more than two logics balance these and do they experience more or less mission drift than hybrids with two logics? The findings of this study suggest that SOHOs might be less inclined to experience mission drifts if the entrepreneurs behind them are oriented towards changing systems and achieving net-positive sustainability while considering the social sustainability of present and future generations and taking into account global socio-ecological systems, not just local impacts. To do so, money must be seen as a necessary means to that end.

Certain limitations apply to this review which warrant consideration. Given the number of concepts and terms used for these organisations in different disciplines, we have not aimed for the review to be so comprehensive as to have covered all the relevant articles. However, it is believed that the rigorous approach taken has revealed how SOHOs differ from traditional, social, and environmental enterprises and provides a valid overview of the actual and potential outcomes and impacts of SOHOs on promoting sustainability transformations.

Furthermore, although we argue that transforming organisations towards SOHO models has the potential to be a key intervention point for promoting sustainability transformations, the transformative effect of new business modes depends on the selective (enabling/dis-enabling) forces of the environments in which SOHOs operate, and the extent to which they can significantly change detrimental and toxic relationships between individuals, communities, societies, and biophysical systems, and put them on positive pathways of development. Despite many SOHOs being designed with good intentions and positive impacts, these can also result in unintended negative consequences. These negative effects may derive from rebound effect of extending consumption to new populations or even excluding people and communities from ecological benefits now reserved for the few or exploiting poor distant communities for their cheap labour. 
Unless SOHOs are able to address these sustainability challenges using a multi-scale, long-term and socially-ecologically coupled perspective, their narratives and actions could well perpetuate rather than ameliorate systemic problems like climate change and social vulnerability. However, if these negative consequences can be addressed as fully as possible, e.g., through institutional innovation and mobilisation, SOHOs could play a decisive role of organising collective action to transform global systems towards regenerative sustainability.

Acknowledgements This research has received funding from the European Union's Horizon 2020 research and innovation programme under Grants Agreements no. 642018, (GREEN-WIN project) and no. 884565 (TIPPING ${ }^{+}$project). We would like to thank Diana Mangalagiu and Yuge Ma for their advice and contributions to the research and to Mark Hirons, Gina Ziervogel and Aoife Haney for providing invaluable comments and suggestions for how to improve the paper. We also thank three anonymous reviewers for very helpful comments.

Open Access This article is licensed under a Creative Commons Attribution 4.0 International License, which permits use, sharing, adaptation, distribution and reproduction in any medium or format, as long as you give appropriate credit to the original author(s) and the source, provide a link to the Creative Commons licence, and indicate if changes were made. The images or other third party material in this article are included in the article's Creative Commons licence, unless indicated otherwise in a credit line to the material. If material is not included in the article's Creative Commons licence and your intended use is not permitted by statutory regulation or exceeds the permitted use, you will need to obtain permission directly from the copyright holder. To view a copy of this licence, visit http://creativecommons.org/licenses/by/4.0/.

\section{References}

Alberti FG, Varon Garrido MA (2017) Can profit and sustainability goals co-exist? New business models for hybrid firms. J Bus Strategy 38(1):3-13

Allen JC, Malin S (2008) Green entrepreneurship: a method for managing natural resources? Soc Nat Resour 21(9):828-844. https:// doi.org/10.1080/08941920701612917

Anderson TL, Leal D (2001) Free market environmentalism, revised. Springer, New York

Ashforth BE, Reingen PH (2014) Functions of dysfunction: managing the dynamics of an organizational duality in a natural food cooperative. Adm Sci Q 59(3):474-516. https://doi. org/10.1177/0001839214537811

Asrar GR, Lucas P, van Vuuren D, Pereira L, Vervoort J, Bhargava R (2019) Outlooks in GEO-6-global environment outlook (GEO-6): healthy planet, healthy people chapter 19. Global Environment Outlook (GEO-6): Healthy Planet, Healthy People, pp 463-470

Battilana J, Dorado S (2010) Building sustainable hybrid organizations: the case of commercial microfinance organizations. Acad Manag J 53(6):1419-1440. https://doi.org/10.5465/amj.2010.57318391

Battilana J, Lee M (2014) Advancing research on hybrid organizinginsights from the study of social enterprises. Acad Manag Ann 8(1):397-441. https://doi.org/10.1080/19416520.2014.893615

Battiliana J, Lee M, Walker J, Dorsey C (2012) In search of the hybrid ideal. Stanford Social Innovation Review 50-55
Berno T (2017) Social enterprise, sustainability and community in postearthquake Christchurch. J Enterp Communities 11(1):149-165

Billis D (2010) Towards a theory of hybrid organizations. Hybrid organizations and the third sector. Palgrave Macmillan, Basingstoke, pp 46-69

Boyd B, Henning N, Reyna E, Wang D, Welch M, Hoffman AJ (2017) Hybrid organizations: new business models for environmental leadership. Routledge, London

Bull M (2008) Challenging tensions: critical, theoretical and empirical perspectives on social enterprise. Int J Entrep Behav Res 14(5):268-275

Butz C, Liechti J, Bodin J, Cornell SE (2018) Towards defining an environmental investment universe within planetary boundaries. Sustain Sci. https://doi.org/10.1007/s11625-018-0574-1

Chliova M, Mair J, Vernis A (2020) Persistent category ambiguity: the case of social entrepreneurship. Organ Stud 0170840620905168

Dacin MT, Dacin PA, Tracey P (2011) Social entrepreneurship: a critique and future directions. Organ Sci 22(5):1203-1213

de Jong M, Joss S, Schraven D, Zhan C, Weijnen M (2015) Sustainable-smart-resilient-low carbon-eco-knowledge cities; making sense of a multitude of concepts promoting sustainable urbanization. J Clean Prod 109:25-38. https://doi.org/10.1016/j.jclep ro.2015.02.004

Dean TJ, McMullen, j. S. (2007) Toward a theory of sustainable entrepreneurship: Reducing environmental degradation through entrepreneurial action. J Bus Ventur 22(1):50

Diaz-Correa JE, Lopez-Navarro MA (2018) Managing sustainable hybrid organisations: a case study in the agricultural sector. Sustainability. https://doi.org/10.3390/su10093010

Doherty B, Haugh H, Lyon F (2014) Social enterprises as hybrid organizations: a review and research agenda. Int J Manag Rev 16(4):417-436. https://doi.org/10.1111/ijmr.12028

Duke D (2016) Why don't BOP ventures solve the environmental problems they initially set out to address? Org Environ 29(4):508-528

Ebrahimi P, Mirbargkar SM (2017) Green entrepreneurship and green innovation for SME development in market turbulence. Eurasian Bus Rev 7(2):203-228. https://doi.org/10.1007/s4082 1-017-0073-9

Farmer J, Hepburn C, Ives M, Hale T, Wetzer T, Mealy P, Way R (2019) Sensitive intervention points in the post-carbon transition. Science 364(6436):132-134

Field CB, Barros VR, Mach K, Mastrandrea M (2014) Climate change 2014: impacts, adaptation, and vulnerability, vol 1. Cambridge University Press, Cambridge

Field CB, Barros VR, Mastrandrea MD, Mach KJ, Abdrabo M-K, Adger N, Barnett J (2014) Summary for policymakers. In: Climate change 2014: impacts, adaptation, and vulnerability. Part A: global and sectoral aspects. Contribution of working group II to the fifth assessment report of the intergovernmental panel on climate change. Cambridge University Press, pp 1-32

Folke C, Österblom H, Jouffray J-B, Lambin EF, Adger WN, Scheffer $M$ et al (2019) Transnational corporations and the challenge of biosphere stewardship. Nat Ecol Evol 3(10):1396-1403

Fordham AE, Robinson GM (2019) Identifying the social values driving corporate social responsibility. Sustain Sci 14(5):1409-1424. https://doi.org/10.1007/s11625-019-00720-w

Frediani A, Walker J, Butcher S (2014). Participatory informal settlement upgrading and well-being in Kisumu, Kenya. The Bartlett Development Planning Unit

Friedland R, Alford RR, Powell WW, DiMaggio PJ (1991). In: Powell W, Dimaggio,PJ (eds) The new institutionalism in organizational analysis, pp 232-263

Gast J, Gundolf K, Cesinger B (2017) Doing business in a green way: a systematic review of the ecological sustainability 
entrepreneurship literature and future research directions. J Clean Prod 147:44-56

Gibbs D (2006) Sustainability entrepreneurs, ecopreneurs and the development of a sustainable economy. Greener Manag Int 55:63-78

Gifford R, Comeau LA (2011) Message framing influences perceived climate change competence, engagement, and behavioral intentions. Glob Environ Change 21(4):1301-1307

Gismondi M, Cannon K (2012) Beyond policy "lock-in"? The social economy and bottom-up sustainability. Can Rev Soc Policy 67:58-73

Glavas A, Mish J (2015) Resources and capabilities of triple bottom line firms: going over old or breaking new ground? J Bus Ethics 127(3):623-642. https://doi.org/10.1007/s10551-014-2067-1

Greenwood R, Suddaby R (2006) Institutional entrepreneurship in mature fields: The big five accounting firms. Acad Manag J 49(1):27-48

Greenwood R, Suddaby R, Hinings CR (2002) Theorizing change: the role of professional associations in the transformation of institutionalized fields. Acad Manag J 45(1):58-80

Haigh N, Hoffman AJ (2012) Hybrid organizations: the next chapter of sustainable business. Org Dyn 41(2):126-134. https://doi. org/10.1016/j.orgdyn.2012.01.006

Haigh N, Hoffman AJ (2014) The new heretics: hybrid organizations and the challenges they present to corporate sustainability. Org Environ 27(3):223-241. https://doi.org/10.1177/1086026614 545345

Hall JK, Daneke GA, Lenox MJ (2010) Sustainable development and entrepreneurship: past contributions and future directions. J Bus Ventur 25(5):439-448

Harini V, Meenakshi DT (2012) Green entrepreneurship alternative (business) solution to save environment. Asia Pac J Manag Entrep Res 1(3):79-89

Hendrickson LU, Tuttle DB (1997) Dynamic management of the environmental enterprise: a qualitative analysis. J Org Change Manag 10(4):363-382

Hestad D (2019) Organising urban sustainability transformations. University of Oxford, Oxford

Hestad D, Tàbara JD, Thornton TF (2020) Transcending unsustainable dichotomies in management: lessons from Sustainability-Oriented Hybrid Organisations in Barcelona. J Clean Prod 244:118766

Hiller JS (2013) The benefit corporation and corporate social responsibility. J Bus Ethics 118(2):287-301

Hockerts K, Muñoz P, Janssen F, Nicolopoulou K (2018) Advancing sustainable entrepreneurship through substantive research. Int J Entrep Behav Res 24(2):322-332. https://doi.org/10.1108/ IJEBR-03-2018-427

Hoffman AJ, Badiane KK, Haigh N (2012) Hybrid organizations as agents of positive social change: bridging the for-profit and non-profit divide. Using a positive lens to explore social change and organizations: building a theoretical and research foundation, 131

Holt D, Littlewood D (2015) Identifying, mapping, and monitoring the impact of hybrid firms. Calif Manag Rev 57(3):107-125

Hörisch J (2015) The role of sustainable entrepreneurship in sustainability transitions: a conceptual synthesis against the background of the multi-level perspective. Adm Sci 5(4):286. https://doi. org/10.3390/admsci5040286

Hörisch J, Kollat J, Brieger SA (2017) What influences environmental entrepreneurship? A multilevel analysis of the determinants of entrepreneurs' environmental orientation. Small Bus Econ 48(1):47-69. https://doi.org/10.1007/s11187-016-9765-2

Huybrechs F, Bastiaensen J, Van Hecken G (2019) Exploring the potential contribution of green microfinance in transformations to sustainability. Curr Opin Environ Sustain 41:85-92
Hysa X, Zerba E, Calabrese M, Bassano C (2018) Social business as a sustainable business model: making capitalism anti-fragile. Sustain Sci. https://doi.org/10.1007/s11625-018-0566-1

Isaak R (2016) The making of the ecopreneur. In: Schaper M (ed) Making ecopreneurs. Routledge, London, pp 63-78

Jay J (2013) Navigating paradox as a mechanism of change and innovation in hybrid organizations. Acad Manag J 56(1):137-159

Jolink A, Niesten E (2015) Sustainable development and business models of entrepreneurs in the organic food industry. Bus Strategy Environ 24(6):386-401

Jones JA, Donmoyer R (2015) Multiple meanings of social entrepreneurship and social enterprise and their implications for the nonprofit field. J Nonprofit Educ Leadersh 5(1):12-29

Kearins K, Collins E, Tregidga H (2010) Beyond corporate environmental management to a consideration of nature in visionary small enterprise. Bus Soc 49(3):512-547

Kirkwood J, Walton S (2010) What motivates ecopreneurs to start businesses? Int J Entrep Behav Res 16(3):204-228. https://doi. org/10.1108/13552551011042799

Lenox M, York JG (2011) Environmental entrepreneurship. In: Hoffman AJ, Bansal T (eds) The Oxford handbook of business and natural environment, pp 70-92

Loorbach D, Wijsman K (2013) Business transition management: exploring a new role for business in sustainability transitions. J Clean Prod 45:20-28. https://doi.org/10.1016/j.jclep ro.2012.11.002

Lyons K, Westoby P (2014) Carbon colonialism and the new land grab: plantation forestry in Uganda and its livelihood impacts. J Rural Stud 36:13-21

Maggs D, Robinson J (2016) Recalibrating the anthropocene: sustainability in an imaginary world. Environ Philos 13(2):175-194

Mars MM, Lounsbury M (2009) Raging against or with the private marketplace? Logic hybridity and eco-entrepreneurship. J Manag Inq 18(1):4-13

Martí I (2018) Transformational business models, grand challenges, and social impact. J Bus Ethics 152(4):965-976. https://doi. org/10.1007/s10551-018-3824-3

Matyas D, Pelling M (2015) Positioning resilience for 2015: the role of resistance, incremental adjustment and transformation in disaster risk management policy. Disasters 39:S1-S18. https://doi. org/10.1111/disa.12107

Millenium Ecosystem Assessment M (2005) Ecosystems and human well-being: synthesis. Island Press, Washington

Muñoz P, Cohen B (2017) Towards a social-ecological understanding of sustainable venturing. J Bus Ventur Insights 7:1-8. https://doi. org/10.1016/j.jbvi.2016.12.001

Muñoz P, Cohen B (2018a) Entrepreneurial narratives in sustainable venturing: beyond people, profit, and planet. J Small Bus Manag $56: 154-176$

Muñoz P, Cohen B (2018b) sustainable entrepreneurship research: taking stock and looking ahead. Bus Strategy Environ 27(3):300322. https://doi.org/10.1002/bse.2000

Nahi T (2016) Cocreation at the base of the pyramid: reviewing and organizing the diverse conceptualizations. Org Environ 29(4):416-437

Nicholls A, Teasdale S (2017) Neoliberalism by stealth? Exploring continuity and change within the UK social enterprise policy paradigm. Policy Polit 45(3):323-341. https://doi.org/10.1332/03055 7316X14775864546490

Nielsen C, Samia PM (2008) Understanding key factors in social enterprise development of the BOP: a systems approach applied to case studies in the Philippines. J Consum Mark 25(7):446-454

O'Brien KL (2012) Global environmental change II: from adaptation to deliberate transformation. Prog Hum Geogr 36(5):667-676. https://doi.org/10.1177/0309132511425767 
O’Brien KL, Sygna L (2013). Responding to climate change: the three spheres of transformation. In: Proceedings of transformation in a changing climate

Ocasio W (1997) Towards an attention-based view of the firm. Strateg Manag J 18(S1):187-206

Olofsson S, Hoveskog M, Halila F (2018) Journey and impact of business model innovation: the case of a social enterprise in the scandinavian electricity retail market. J Clean Prod 175:70-81. https ://doi.org/10.1016/j.jclepro.2017.11.081

Otto IM, Donges JF, Cremades R, Bhowmik A, Hewitt RJ, Lucht W, Doe SS (2020) Social tipping dynamics for stabilizing Earth's climate by 2050. Proc Natl Acad Sci 117(5):2354-2365

Pache AC, Santos F (2011) Inside the hybrid organization-an organizational level view of responses to conflicting institutional demands. ESSEC Working Paper 11001

Parrish BD (2010) Sustainability-driven entrepreneurship: principles of organization design. J Bus Ventur 25(5):510-523. https://doi. org/10.1016/j.jbusvent.2009.05.005

Parrish BD, Foxon TJ (2006) Sustainability entrepreneurship and equitable transitions to a low-carbon economy. Greener Manag Int 55:47-62. https://doi.org/10.9774/GLEAF.3062.2006.au.00006

Pastakia A (1998) Grassroots ecopreneurs: change agents for a sustainable society. J Org Change Manag 11(2):157-173

Pastakia A (2002) Assessing Ecopreneurship in the context of a developing country. Greener Manag Int 38

Pellicer-Sifres V, Belda-Miquel S, Cuesta-Fernandez I, Boni A (2018) Learning, transformative action, and grassroots innovation: Insights from the Spanish energy cooperative Som Energia. Energy Res Soc Sci 42:100-111. https://doi.org/10.1016/j. erss.2018.03.001

Raufflet E, Gouin J-F, Berranger A (2008) Innovation in business-community partnerships: evaluating the impact of local enterprise and global investment models on poverty, bio-diversity and development. Corp Gov 8(4):546-556. https://doi.org/10.1108/14720 700810899266

Reynolds E (2017) Collective evolution and next-stage organizations. Spanda J VII(1):137-145

Robinson J, Cole RJ (2015) Theoretical underpinnings of regenerative sustainability. Build Res Inf 43(2):133-143

Romanelli E (1991) The evolution of new organizational forms. Ann Rev Sociol 17(1):79-103

Roodman D (2012) Due diligence: an impertinent inquiry into microfinance. CGD Books, London

Sanchez P, Ricart JE (2010) Business model innovation and sources of value creation in low-income markets. Eur Manag Rev 7(3):138-154

Santos FM (2012) A positive theory of social entrepreneurship. J Bus Ethics 111(3):335-351

Sarah EAD, Clifford A (2007) Ecopreneurship-a new approach to managing the triple bottom line. J Org Change Manag 20(3):326345. https://doi.org/10.1108/09534810710740164

Schaefer K, Corner PD, Kearins K (2015) Social, environmental and sustainable entrepreneurship research: what is needed for sustainability-as-flourishing? Org Environ 28(4):394-413

Schaltegger S, Wagner M (2011) Sustainable entrepreneurship and sustainability innovation: categories and interactions. Bus Strategy Environ 20(4):222-237. https://doi.org/10.1002/bse.682
Schaper M (2002) The essence of ecopreneurship. Greener Manag Int (38):26-30

Scott RW, Meyer JW (1994) Institutional environments and organizations: structural complexity and individualism. Sage

Sharma RR, Mukherji S (2015) Organizational transformation for sustainable development: a case study. In: Albach H, Meffert H, Pinkwart A, Reichwald R (eds) Management of permanent change. Springer Gabler, Wiesbaden, pp 195-216

Shellenberger M, Nordhaus T (2004) The death of environmentalism. Global warming politics in a post-environmental world. http:// www.thebreakthrough.org/images/Death_of_Environmentalis m.pdf. Accessed 18 Aug 2019

Simmel G (2004) The philosophy of money. Routledge, London

Smallbone D, Evans M, Ekanem I, Butters S (2001) Researching social enterprise: final report to the small business service. Centre for Enterprise and Economic Development Research, Middlesex University Business School, Middlesex University, UK

Smith WK, Gonin M, Besharov ML (2013) Managing social-business tensions: a review and research agenda for social enterprise. Bus Ethics Q 23(3):407-442

Stecker MJ (2016) Awash in a sea of confusion: benefit corporations, social enterprise, and the fear of "greenwashing." J Econ Issues 50(2):373-381. https://doi.org/10.1080/00213624.2016.1176481

Stubbs W (2017) Sustainable entrepreneurship and B corps. Bus Strategy Environ 26(3):331-344

Tàbara JD, Pahl-Wostl C (2007) Sustainability learning in natural resource use and management. Ecol Soc 12(2):1-15

Tàbara JD, Frantzeskaki N, Hölscher K, Pedde S, Kok K, Lamperti F, Berry P (2018) Positive tipping points in a rapidly warming world. Curr Opin Environ Sustain 31:120-129

Teasdale S (2012) What's in a name? Making sense of social enterprise discourses. Public Policy Adm 27(2):99-119

Thompson N, Kiefer K, York JG (2011) Distinctions not dichotomies: exploring social, sustainable, and environmental entrepreneurship. Soc Sustain Entrep. https://doi.org/10.1108/S1074 -7540(2011)0000013012

Tranfield D, Denyer D, Smart P (2003) Towards a methodology for developing evidence-informed management knowledge by means of systematic review. Br J Manag 14(3):207-222

Turcato C, Barin-Cruz L, Eugenio Avila P (2012) Internal and external pressures. Learn Org 19(1):38-57. https://doi.org/10.1108/09696 471211190356

Westley F, Antadze N (2010) Making a difference: strategies for scaling social innovation for greater impact. Innov J 15(2):1-19

Wilson F, Post JE (2013) Business models for people, planet (\& profits): exploring the phenomena of social business, a market-based approach to social value creation. Small Bus Econ 40(3):715-737

Ziervogel G, Cowen A, Ziniades J (2016) Moving from adaptive to transformative capacity: Building foundations for inclusive, thriving, and regenerative urban settlements. Sustainability 8(9):955

Publisher's Note Springer Nature remains neutral with regard to jurisdictional claims in published maps and institutional affiliations. 